Version: Postprint (Accepted Manuscript)

2015

\title{
How to Defame a God: Public Selfhood in the Maharaj Libel Case
}

J. Barton Scott

Permanent link of this paper: http://hdl.handle.net/1807/95441

\section{Important Notes}

Always cite the Version of Record (VoR: final publisher's version) so that the author(s) will receive recognition through services that track citation counts, e.g., Scopus. When you are unable to access the VoR, the citation needs to include the word, Postprint (Accepted Manuscript).

Visit Publisher's Site for the VoR: https://doi.org/10.1080/00856401.2015.1050161 


\title{
How to Defame a God: Public Selfhood in the Maharaj Libel Case
}

\author{
J. Barton $\mathrm{Scott}^{1}$ \\ 1 Department of Historical Studies and Department for the Study of Religion, University of Toronto, Toronto, ON, Canada
}

\begin{abstract}
This article argues that competing ideas about the nature of public selfhood structured the Maharaj Libel Case, as well as colonial publics more broadly. Jadunathji Maharaj had, in effect, lost his libel suit even before it went to court. For libel law, the essence of the human person is a private self that owns various forms of property, including the public persona known as 'reputation.' For the Hindu Pushtimarg, meanwhile, the Maharaj was considered an incarnation of Krishna; his religious or public self preceded and was the ontological ground for his merely personal being. To compare these two conceptualizations of the self is to see how selfhood became an important site for the articulation of the public in colonial India.
\end{abstract}

\section{KEYWORDS}

Legal history, Libel, Modern Hinduism, Secularism, Pushtimarg, Bhakti, Publics

Hailed as 'the greatest trial of modern times since the trial of Warren Hastings', the Maharaj Libel Case of 1862 remains an emblematic event in the history of modern Hinduism. ${ }^{1}$ The basic facts of the case are simple enough. The defendant was reform-minded journalist Karsandas Mulji, whose 1860 newspaper article on 'The Primitive Religion of the Hindus and the Present Heterodox Opinions' had questioned the legitimacy of the Pushtimarg or Vallabhacharya sampradaya, a Hindu sect prevalent among Bombay's Gujaratis. The plaintiff was Jadunathji Brizratanji, the eponymous Maharaj (the religious title given to leaders of the sect), whom the article accused of having 'defiled' his female devotees. ${ }^{2}$ To clear his good name, the Maharaj took the unprecedented step of filing a libel suit in the Bombay Supreme Court. As is often the case with libel hearings, the court's

Research for this article was made possible by grants from Montana State University and the American Institute for Indian Studies. For feedback on earlier versions of the essay, I would like to thank the participants in the 2014 Northwestern University workshop on 'Imagining the Public in Colonial India' and the 2014 National Humanities Center SIAS Summer Institute on 'Cultural Encounters'. I would also like to thank the two peer reviewers for South Asia, as well as Mitch Numark, Dan Sheffield, Amrita Shodhan, Usha Thakkar, and especially Mitra Sharafi.

1 B. N. Motiwala, Karsondas Mulji: A Biographical Study (Bombay: Karsondas Mulji Centenary Celebration Committee, 1935), p. 33. 
attention quickly turned away from the defendant and toward the plaintiff: to determine whether Mulji's defamatory publication qualified as libel (the written form of the tort of defamation), the two judges had to assess the truth of its claims. Experts like missionary scholar John Wilson contrasted Pushtimargi teachings with those of more 'orthodox' Hindu texts. Much more damningly, several witnesses vividly described Jadunathji's erotic escapades. The Maharaj's fate was sealed when two different doctors testified to having treated him for syphilis by prescribing the external application of mercurial 'blackwash'. Based largely on the strength of this medical evidence, both judges acquitted Mulji of the charge of libel, although on slightly different grounds. They agreed that the defamatory article was 'justified', and thus not libelous, in that its allegations were true; they disagreed as to whether its publication to a broad reading audience was appropriate.

For most of a century, the trial was typically understood as 'an eloquent sermon on religion and pseudo-religion', in which the reformist Mulji liberated his caste-fellows from oppressive priestly rule. ${ }^{3}$ A more recent scholarship has shown that this is, at best, a partial story: 'liberation' from priestly rule facilitated the emergence of new forms of social control, ranging from the codification of an Orientalist-juridical Hinduism that could meet the bureaucratizing demands of the colonial state to the regulation of female domesticity by bourgeois Hindu men. ${ }^{4}$ One of just a handful of events in the history of modern Hinduism that has begun to accrue a relatively thick interpretive tradition in which different layers of cultural criticism (reformist-liberal, feminist, postcolonial) overlap and intersect, the Maharaj Libel Case helps us to see not only how several generations of scholars have construed the problematic of 'Hindu modernity', but also how the colonial archive can continue to structure contemporary theoretical debates-including, as I will suggest, debates about the genealogy of 'the public' in South Asia.

The Maharaj Libel Case is typically seen as a classic drama of colonial misrecognition, and with good reason: representatives of the Pushtimarg could not speak in court without their words taking on unanticipated shape, changing meanings as they changed context. This article confirms and elaborates on this narrative by arguing that British libel law and Pushtimargi devotionalism implied distinct and mutually incompatible models of human personhood that were in substantial tension during the trial. At the same time, however, I also ask whether cultural encounters like this one created the conditions of possibility for the emergence of novel social forms that cut across the familiar divide between colonizer and colonized. Here, I suggest that the colonial print public and

2 Report of the Maharaj Libel Case and of the Bhattia Conspiracy Case, Connected With It (Bombay: Bombay Gazette Press, 1862), p. 3. Henceforth referred to in text as $M L C$.

3 Maharaj Libel Case: Including Bhattia Conspiracy Case (Bombay: D. Lukhmidass, 1911), p. i. See also Charles Heimsath, Indian Nationalism and Hindu Social Reform (Princeton: Princeton University Press, 1964), pp. 103-105; Makrand Mehta, 'Maharaj Libel Case: A Study in Social Change in Western India in the Nineteenth-Century', in Indo-Asian Culture, Vol. 19, no. 4 (1970), pp. 26-39. For a reconsideration of this narrative, see J. Barton Scott, 'Luther in the Tropics: Karsandas Mulji and the Colonial "Reformation" of Hinduism', Journal of the American Academy of Religion (forthcoming).

4 David L. Haberman, 'On Trial: The Love of the Sixteen Thousand Gopees', in History of Religions Vol. 33, no. 1 (1993), pp. 44-70; Jürgen Lütt, 'From Krishnalila to Ramarajya: A Court Case and Its Consequences for the Reformulation of Hinduism', in Vasudha Dalmia and Heinrich von Stietencron (eds.), Representing Hinduism: The Construction of Religious Traditions and National Identity (New Delhi: Sage Publications, 1995), pp. 142-153; Amrita Shodhan, 'Women in the Maharaja Libel Case: A Re-examination', in Indian Journal of Gender Studies, Vol. 4, no. 2 (1997), pp.123-139; Usha Thakkar, 'Puppets on the Periphery: Women and Social Reform in $19^{\text {th }}$ Century Gujarati Society', in Economic and Political Weekly, Vol. 32, no.1-2 (January 1997), pp. 46-58. 
Pushtimargi theology relied on remarkably parallel epistemologies of exposure that could, perhaps, have been productively combined. This did not happen. But, as I explore in greater depth elsewhere, by positioning the self as a key site for the articulation of the colonial public, the Maharaj Libel Case did anticipate what would later become a major idiom of colonial politics: the early-twentiethcentury 'ethical turn' perhaps most famously associated with M. K. Gandhi's writings on 'self-rule'. In their Gujarati-language writings of the late 1850s and early 1860s, Mulji and the Maharaj had both positioned the self as the primary object of religious reform and did so in a way that drew on Hindu, Protestant, and liberal techniques of self-formation. ${ }^{6}$ Here, in complementary fashion, I hope to show that religious reformers were not alone in problematizing the self at this time; major public institutions were doing much the same. Indeed, it was only by reshaping selfhood that the colonial 'public' could emerge as such.

\section{A Public Spirit}

In his much-quoted closing opinion, Puisne Judge Joseph Arnould pronounced that Mulji had only been doing his 'duty' when he exposed the Maharaj's misdeeds: 'A public journalist is a public teacher: the true function of the press, that by virtue of which it has rightly grown to be one of the great powers of the modern world-is the function of teaching, elevating and enlightening those who fall within the range of its influence' (MLC, 205). Arnould's remarks might seem commonsensical. Implicitly defining the public as consisting of 'those who fall within the range' of newspapers, Arnould renders the phrase 'public journalist' all but redundant: print and the public are constitutively interlinked. Here, contrary to standard accounts of the liberal public sphere as independent of the state, we can see how the British state worked to define and regulate the Indian public through institutions like the courts.

Arnould's claim about print is, of course, culturally and historically specific, caught up with the extension of the eighteenth century's republic of letters from Britain to its overseas colonies, including India. ${ }^{7}$ To provincialize it, we need only follow it in its travels. Like other terms in the cultural lexicon of modern English (e.g. religion), public cannot be translated into South Asian languages without significant remainder.

Apparently aware of this fact, some colonial writers simply transliterated the word (as pablik) into languages like Hindi. ${ }^{8}$ Others sought vernacular equivalents to it. Karsandas Mulji, our

5 Shruti Kapila, 'Self, Spencer, and Swaraj: Nationalist Thought and Critiques of Liberalism, 1890-1920', Modern Intellectual History, Vol. 4, no. 1 (2007): pp. 109-127.

6 J. Barton Scott, Spiritual Despots: Modern Hinduism, 'Priestcraft', and the Genealogies of Self-Rule (Chicago: University of Chicago Press, forthcoming).

7 For an analysis of one corner of this colonial world, see Michael Warner, The Letters of the Republic: Publication and the Public Sphere in Eighteenth Century America (Cambridge, MA: Harvard University Press, 1992). AngloIndian newspapers situated themselves within the larger world of Enlightenment letters by a number of means, including literary quotation. The Poona Observer's motto, for instance, quotes Daniel Defoe's claim that the 'impartial writer' dedicated to 'truth' should 'expect martyrdom on both sides.' Poona Observer (15 Feb. 1862), p.79.

8 See for example Shriman Munshi Dayaram Sahib Purv Tahasildar, Maharsi Dayanandcaritamrt (Meerut: Swami Press, 1904), pp. i-ii; Lala Lajpat Ray, Maharsi Svami Dayanand Sarasvati aur Unka Kam, trans. Gopaldas Devgun Sharma (New Delhi: Sarvadeshak Arya Pratinidhi Sabha 1967 [1898]), p. 275. 
defendant, is a case in point. In an 1858 essay, he chided Bombay for its 'Want of Public Spirit and Independence'. ${ }^{9}$ This is a title with an implicit double meaning. Not only, according to Mulji, do some of Bombay's most prominent citizens lack the courage to stand up for their views on controversial topics like widow remarriage. Gujarati even lacks words for what Mulji positions as distinctively British 'virtues' (gun). In translating public into Gujarati, however, Mulji cannot quite close this gap: to translate is to proliferate shades of meaning.

Mulji is hardly the only person to have identified 'public spirit' as central to the political life of modern Britain; Jürgen Habermas does much the same. ${ }^{10}$ But in trying to translate 'the public', Mulji disarticulates two distinct senses of the word that the English liberal tradition had only provisionally reconciled. According to the Oxford English Dictionary, the word public can be used to describe that which is 'open to observation' and 'carried out without concealment', as well as anything 'of or relating to the people as a whole'. Mulji's Gujarati 'jaher himat' ('public spirit') has a much greater affinity for the first of these meanings. Derived from the Arabic verb to appear, the Urdu adjective zahir denotes the outward, exterior, apparent, open, or overt. ${ }^{11}$ While in contemporary Gujarati, it can indicate that which belongs to all people (the sarvajanak), as in the phrases for 'public transit' (jaher vahan) and 'public service' (jaher seva), etymologically its more fundamental sense is as the opposite of 'secret' ( $g u p t$, which is in turn not entirely equivalent to the Urdu, batin). ${ }^{12}$ That jaher cannot quite encompass both senses of the English public is suggested by Mulji's translation of Judge Arnould's closing speech: 'A public writer [jaher lakhnar] is counted as the people's public teacher [lokono jaher shikshak]. ${ }^{13}$ In English, a 'public teacher' can, however tautologically, address 'the public' (i.e. a set of persons defined by having been so addressed). In 1860s Gujarati, it would seem, jaher could not designate audience in quite this way; to be fully public, in the doubled sense of that term, an 'open writer' must be tied to 'the people' (lok) explicitly.

The public here is that which sutures 'the people' to an attitude of openness, or which brings the people into being in relation to such an attitude. It is, in short, not just a social formation; it is also a formation of the subject. Publics imply an orientation of the self- whether a way of being in public that lays the self open to the scrutiny of unknown others, or a writing of the self into the outward surface of a text. To analyze the history of colonial publics, then, we also need to pursue the history of colonial subjectivity.

In what follows, I pursue two different inquiries related to this broader set of concerns. On one hand, I distinguish between the two distinct models of human personhood implied by British libel law and Pushtimargi devotionalism; on the other, I suggest that both these cultural formations used parallel tropes of exposure, such that each can be understood as hailing a subject

9 Karsandas Mulji, Nibandhmaḷa: Samsar Sambandhi Visayo (Mumbai: Union Press, 1870), pp. 95-98.

10 Jürgen Habermas, The Structural Transformation of the Public Sphere, trans. Thomas Burger (Cambridge, MA: MIT Press, 1989), pp. 93-95.

11 John T. Platts, A Dictionary of Urdu, Classical Hindi, and English (Oxford: Oxford University Press, 1974), p. 755.

12 Sarth Gujarati Jodanikosh (Ahmedabad: Gujarat Vidyapiṭh, 2006), p. 348. The standard antonym in Urdu would, of course, be batin.

13 [Karsandas Mulji], trans., Maharaj Laibal Kes, tatha Eni Sathe Sambandh Sakhnar Bhația Kanspiresi Kesno Riport (Mumbai: Daftar Ashakara Chapakana, 1862), p. 176. 
constituted by a desire for hidden or veiled knowledge. While my characterization of both libel law and Pushtimargi devotion is necessarily schematic, I try to present the cultures that collided in this 1862 courtroom not as reified or timeless entities, but as the mobile products of ongoing histories; where I schematize, I do so in the hope that the use of heuristic ideal types can illuminate cultural phenomena, the complexity of which inevitably exceeds them.

\section{Making the Bombay Public}

The history of Bombay is inseparable from the economic expansion of the British Empire across South Asia and the Indian Ocean world. It is also inseparable from the history of religionof the Hindus, Muslims, Jews, Jains, Christians, and Parsis who crisscrossed India, Africa, and East and Southeast Asia to make their city one of the nineteenth century's most cosmopolitan. With modern technologies like the steamship and the printing press enabling a lush proliferation of devotional practices, religion became an especially productive cultural field during this period, whether politicized in a Ganesh festival or aestheticized on a cinema screen. ${ }^{14}$

Bombay changed profoundly during the nineteenth century, and perhaps never more rapidly than in the 1860s. This was the time of the cotton bubble, the transition to Crown rule, and the formation of proto-nationalist groups like Dadabhai Naoroji's East India Association. Within twenty years, industrial cotton mills and neo-Gothic buildings constructed largely on infill would decisively transform the urban landscape. Other forces, meanwhile, were remaking the city's social terrain. Bombay had long been comprised of distinct communities demarcated by caste, language, and religion. Parsis, Bohras, Bhattias, and other groups intermixed in street and market, but the center of civic life arguably laid elsewhere - in the panchayats, mahajans, and other bodies that governed these 'encapsulated' communities. ${ }^{15}$ Indeed, the word 'community' has been said to obscure the way in which these groups functioned as self-governing political spaces; it is probably better, as Amrita Shodhan suggests, to term them 'caste polities'. ${ }^{16}$

Sometime after the 1850s, Bombay's center of civic gravity shifted away from these polities and toward an emergent public sphere closely associated with the colonial milieu. There were several reasons for this shift, ranging from the relatively abstract pressure of the market (which, as a cultural form, required the reconstitution of communally embedded subjects as autonomous individuals within an undifferentiated public) to more concrete changes in urban institutions. ${ }^{17}$ Bombay's 'merchant princes' or shetias had been collaborating across community lines for decades; after the 1850s, however, their 'concerted action' against the British (to use Naoroji's phrase) amplified the

14 Gyan Prakash, Mumbai Fables (Princeton: Princeton University Press, 2011); Nile Green, Bombay Islam (Cambridge: Cambridge University Press, 2011); Teena Purohit, The Agha Khan Case: Religion and Identity in Colonial India (Cambridge, Mass.: Harvard University Press, 2012); Raminder Kaur, Performative Politics and the Cultures of Hinduism (Delhi: Permanent Black, 2003).

15 J. C. Masselos, Towards Nationalism: Group Affliations and the Politics of Public Associations in NineteenthCentury Western India (Bombay: Popular Prakashan, 1974).

16 Amrita Shodhan A Question of Community: Religious Groups and Colonial Law (Calcutta: Samya, 2001).

17 Ritu Birla, Stages of Capital: Law, Culture, and Market Governance in Late Colonial India (Durham, NC: Duke University Press, 2009). 
significance of this collaboration. Just as important was the rising tide of 'Young Bombay', the English-educated 'intelligentsia' that advocated for social reform in newly founded newspapers, libraries, and debating societies. ${ }^{18}$ Together, these constellated institutions, which existed outside of and in tension with caste polities, comprised the colonial public.

The Maharaj Libel Case demonstrates in miniature how this transition occurred. Bania and Bhattia Mahajans and the Pushtimargi Maharajas had traditionally worked together to resolve conflicts and enforce caste norms. As these traditional alliances began to erode, caste members increasingly turned to the colonial courts to adjudicate conflicts. In doing so, however, they undermined the caste polity's ability to self-govern. Colonial courts, after all, tended to interpret the community's efforts at self-governance as criminal interference with the law (this was especially clear the Bhattia Conspiracy Case that preceded the Maharaj Libel trial proper). Eventually, as Shodhan argues, the shift in civic gravity prompted a transformation in how caste was understood. What had been 'recognized as a political space of debate, dispute, and hierarchy' was now seen primarily as an 'attachment' of an 'individual' subject defined by his or her place within a socially undifferentiated public sphere. Henceforth, caste would function chiefly as a sociological descriptor or 'anachronistic identity' borne by subjects whose political being derived from elsewhere. ${ }^{19}$

The press played an important role in this process. Several kinds of publicity overlapped during Maharaj Libel affair. Some were spectacular, like the quasi-theatrical spaces of the courtroom and police office, which at one point was so packed with 'vast masses of human beings' that it seemed like the floor might collapse. ${ }^{20}$ Others were more intimate, like rumor and gossip. Still others were allegedly supernatural, as when a Poona medium claimed to have received the judges' final opinions days before they were read out in court. ${ }^{21}$ But as a mass-mediated scandal, the Maharaj Libel affair was most quintessentially associated with print-especially Bombay's major Englishlanguage dailies, the Times of India and the Bombay Gazette, and the Gujarati-language Rast Goftar ane Satya Prakash.

As Chief Justice Matthew Sausse observed, if Karsandas Mulji had sincerely wanted to reform his caste, he would have addressed his complaints only to its members. By broadcasting his critique to a wider reading public, Sausse argued, Mulji had renounced his claim to the sort of 'justifying occasion' that would absolve him from the charge of libel. The 'mode of publication,' said Sausse 'quite exceeded the bounds suited to the occasion' (MLC, 199). Mulji may well have agreed with this assessment. By at least one account, he had intended only to introduce reforms from 'within' his caste group, but ultimately 'found to his dismay that he had wrecked more than he had constructed'. ${ }^{22}$ It is possible that he failed to realize that his message could not be readily separated from its medium: to critique caste customs from the pages of a newspaper was to alter the city's social terrain. It was, in the standard period metaphor, to open or 'expose' the caste polity

18 Masselos, Towards Nationalism; Christine Dobbin, Urban Leadership in Western India: Politics and Communities in Bombay City, 1840-1885 (London: Oxford University Press, 1972).

19 Shodhan Question of Community, pp. 118-19, 125.

20 Bombay Gazette (24 Sept. 1861), p. 914; (25 Oct. 1861), p. 1023.

21 Bombay Gazette (12 May 1862), pp. 449-450.

22 N. A. Thoothi, The Vaishnavas of Gujarat (London: Longmans, 1935), p. 97. 
to the prying eyes of the reading public $(M L C, 205)$.

This rhetoric of 'exposure' had ample precedent. Consider Bombay Supreme Court Justice Erskine Perry's comment of the early 1850s:

in courts of justice the veil which shrouds the privacy of Oriental life is necessarily drawn aside, the strong ties which at other times bind together caste and family in pursuit of a common object are loosened under the pressure of stronger individual interests... [such that] the motives, reasonings, and actions of the native population of India are displayed in broad light. ${ }^{23}$

In annexing 'Oriental life' to the imperial information order, in other words, the act of unveiling also alters the subjectivities of those whom it opens to public scrutiny. The bonds of caste and tradition dissolve to reveal self-interested, atomized individuals. Like other such 'subtraction stories', this tale naturalizes the liberal individual by implying that individuality was there all along, underlying the constraints of tradition. It thus draws attention away from the modern social imaginary that forms this individual - an imaginary that consists, among other things, of the very notion of a public sphere defined by an epistemology of exposure. ${ }^{24}$

Press coverage of the Maharaj Libel Case relied heavily on such rhetoric. The Times of India was perhaps most expansive:

Through a long night of superstition and darkness, vile creatures like this Maharaj have been able to make their dens of vice and debauchery seem to their spell-bound followers to be the holy temples of God. But as soon as the morning light comes, the place is found in full corruption and uncleanness; magical spells lose all effect; and all men of a better sort rise disgusted, and at any cost break loose from such a haunt. ${ }^{25}$

The press, we are to surmise, is a force for disenchantment, freeing humanity from magicians whose spells cannot withstand the light of truth. The Bombay Gazette likewise condemned the Maharajas' 'hidden works of darkness' and the 'disgusting and abominable things' that they did 'in secret'. ${ }^{26}$ So did the reformist Rast Goftar and Satya Prakash (amalgamated from the longstanding Parsi newspaper and Mulji's Hindu reform paper). After the trial concluded, it reveled in its titular metaphor, noting that 'in the end, the truth will out. In the end, there is the light of truth'. ${ }^{27} \mathrm{Or}$, as it observed some weeks later, 'Like the light of the sun, the light of the Maharaj's immorality has reached from one end of the earth to the other. ${ }^{28}$

23 Erskine Perry, Cases Illustrative of Oriental Life and the Application of English Law to India, Decided in H. M. Supreme Court at Bombay (London: S. Sweet, 1853), iv.

24 Charles Taylor, A Secular Age (Cambridge, MA: Harvard University, 2007); Warner, Letters of the Republic, p. 82. I analyze the epistemology of exposure in greater depth in 'Miracle Publics: Theosophy, Christianity, and the Coulomb Affair', History of Religions Vol. 49, no. 2 (2009): pp. 172- 196.

25 Times of India (2 May 1862), quoted in Karsandas Mulji, History of the Sect of Maharajas, or Vallabhacharyas in Western India (London: Trübner \& Co, 1865), p. 134.

26 Bombay Gazette (23 Apr. 1862), p. 382.

27 Rast Goftar and Satya Prakash (27 Apr. 1862), p. 199.

28 Rast Goftar and Satya Prakash (18 May 1862), p. 237. 
During the affair, these public exposures returned insistently to a single object: the body of the Maharaj. For both judges, the case hinged on the 'material fact' of Jadunathii's alleged case of the 'French pox'. Sausse concluded that the two doctors (one of whom was leading Bombay citizen Bhau Daji) were telling the truth. Not only had they rigorously kept themselves to giving medical evidence; their testimony had been corroborated by Lakhmidas Khimji, 'one of the leading men in the sect of Vallabhacharyas in Bombay'. Weighing the conflicting evidence, Sausse ruled against the Maharaj. Reasoning that he must have allowed 'personal interests' to overcome his 'respect for truth', Sausse dismissed his entire testimony as compromised (MLC, 203). Arnould followed the senior judge's lead. Thus did the truth of the trial come to rest on a question of sexuality: Jadunathji's body divulged secrets that, once fixed by official forms of knowledge, determined how the public would understand Pushtimargi religion.

Indeed, the precise nature of the Maharaj's flesh was arguably the question at the center of the trial. Was this man a god? A few years earlier, the Rast Goftar (translating the Bombay Guardian) had observed that if 'these divine avatar men enter a court of justice to give their testimony they will become unholy and their high status will be much lessened'. ${ }^{29}$ Not surprisingly, then, Jadunathji's presence in court during the Maharaj Libel Case caused something of a sensation. When he entered the courtroom, heads craned, people stood, and a general whisper of 'he is coming' pulsed through the crowd $(M L C, 166)$. After his arrival, his physical being remained at issue. While in the witness box, Jadunathii fretted that someone might brush up against him from behind. Thomas Anstey, the pleader for the defence, replied harshly: 'Why should you not be touched? ....You are not a God. As for me I won't touch you with a pair of tongs' (ibid., 173).

By at least one measure, the Rast Goftar's prediction that the Maharaj's status would be diminished was necessarily fulfilled. Legally, this was not a case of blasphemy, or offence against religion; it was a case of alleged libel. Jadunathji had sued to protect his 'private property of character' $(M L C, 198)$. In doing so, he presented himself to the court as an ordinary individual and not a divine incarnation of Krishna. His flesh was thus legally transformed: no longer sacred, it was now a form of private property safeguarded by the British state and regulated through state-sanctioned truth procedures like those of scientific medicine.

\section{Genealogies of Libel Law}

One of several overlapping categories that modern states have used to regulate the public, libel also implies a historically and culturally specific vision of what it is to be a self. Libel law hinges on the notion of 'reputation'. This is a notion that, as legal theorist Robert Post explains, establishes 'an image of how people are tied together, or should be tied together, in a social setting,' as well as 'an implicit theory of the relationship between the private and public aspects of the self'. ${ }^{30}$ Two distinct and mutually contradictory concepts of reputation are pertinent here: property and honour. As property, reputation is understood as a form of intangible wealth with implicit monetary value. In the words of one Anglo-Indian legal manual, '[a] man's reputation is his property and, if possible, more valuable than other property. No mere poetic fancy suggested the truth that a good name is

29 Rast Goftar (11 Sept. 1859), p. 453.

30 Robert C. Post, 'The Social Foundations of Defamation Law: Reputation and the Constitution', in California Law Review, Vol. 74, no. 3 (May 1986), pp. 691-742. 
rather to be chosen than great riches'. ${ }^{31}$ Reputation can be cashed in either in everyday financial transactions (a good reputation translates into creditworthiness) or, in exceptional circumstances, through the award of pecuniary damages by a court. It is also the product of labor: an honest merchant or a skilled carpenter builds his reputation through hard work, and, if he loses it, he can in theory build it again. Not so reputation-as-honour. Once lost, it cannot be remade. Whereas the property-concept prevails in market-based industrial societies, the honour-concept characterizes 'deference societies' like that of early modern England. In such societies, a person does not produce his own honour; he claims honour based upon the status with which his social role is invested, thus blurring the distinction between private and public selfhood. The preservation of honour, relatedly, is essential to the maintenance of society as a whole and not just the individuals who comprise it. ${ }^{32}$

The tension between Post's two concepts can be seen concretely in the history of English defamation law (i.e. the law of libel, or written defamation, and slander, its oral counterpart). Although key aspects of English libel law have been said to date to the ancient Mediterranean world, and even to the dawn of writing itself, its most important principles are of more recent derivation. In particular, the early nineteenth century seems to have seen a decided shift away from an honour-based concept of reputation to a property-based concept. Here, I will sketch this shift in what is probably too stark a manner. In actuality, early modern legal forms persisted into the nineteenth century, interlayering with newer forms in complex ways.

Slander against the 'leading men' of England had been considered a crime since the thirteenth century and was a means of protecting a social order based on 'personal bonds of honour and loyalty. ${ }^{33}$ By the eighteenth century, this offence was termed 'seditious libel'. Notably, it refused truth as a defense: a true statement against a highborn man could be even more damaging to the social order than a false one. ${ }^{34}$ It was not until the early nineteenth century that libel law, instead of restricting publication to protect the powerful, was reconceived as a means of protecting private persons. As late as 1818, Francis Holt's Law of Libel included only a single chapter on libel against private persons, devoting space instead to libel against the King's Government (which warrants two chapters), the Two Houses of Parliament, the Courts of Justice, the Law of Nations, Morality and the Law of Nature, and the Christian Religion (the line separating libel and blasphemy, or 'libel against religion', remained thin). ${ }^{35}$ The flurry of treatises on libel that appeared in the 1810s seem to indicate that the concept was changing and in need of recodification at this time, however. As an 1815 review of four such books (including Holt's) quipped: 'The law of libel! There's no such thing. After an attentive perusal of all four of the above treatises, we are still constrained to say that the law of libel is rather a circumlocution-saving phrase than a description of an entity' ${ }^{36}$

31 Ratanlal Ranchhoddas and Dhirajlal Keshavlal Thakore, The English and Indian Law of Torts, (Bombay: Bombay Law Reporter Private Ltd, 1965 [1897]), pp. 159, 164-65.

32 Post, 'Social Foundations', pp. 700-702

33 Norman L. Rosenberg, Protecting the Best Men: An Interpretive History of the Law of Libel (Chapel Hill: University of North Carolina Press, 1986), p. 4.

34 Post, 'Social Foundations', p. 705.

35 Ibid., p. 702; Francis Ludlow Holt, The Law of Libel (New York: Stephen Gould, 1818 [London, 1812]).

36 A Review of the Late Publication on Libel of Messrs. George, Holt, Starkie, E Jones, by a Barrister of the Inner Temple (London: Reed and Hunter, 1815), pp. 7-8. 
The reviewer's specific complaint is that the treatises all based their conception of libel on the preservation of public peace rather than on the standard of truth (i.e. the honour-concept, which preserves the social order at all costs, rather than the property-concept, which strives to correctly calibrate earned and actual reputation).

Libel law was the topic of lively, if sporadic, debate in Parliament from the 1810s through the 1840s, culminating in the enactment of the Libel Act of 1843. Reformers were puzzled by what had come to seem like inconsistencies in defamation law. They were especially keen to align criminal defamation law with the body of civil law that had grown up alongside it to regulate the primarily oral defamation of merchants. For civil defamation suits, truth was an 'absolute justification', as the law could offer no recompense to a person who claimed a reputation he did not deserve. ${ }^{37}$ Reformers wanted to eliminate the distinction between libel and slander (itself only codified in 1812); to introduce the standard of truth into criminal libel; and to temper the absoluteness of truth as justification in civil suits by penalizing 'malicious' publications not in the public interest. In various iterations, these reforms were included in bills proposed between 1816 and 1843, when they were enacted into law - although in a much-reduced form that, as historian Paul Mitchell suggests, was a mere 'shadow' of the reforms proposed. As Mitchell goes on to argue, a fully reformed libel law would become a reality only in colonial contexts, as in New South Wales in 1847, where new laws could take hold more readily than they could in London. ${ }^{38}$

Traces of this history can be seen in the 1860 Indian Penal Code, Chapter 21 of which defines defamation as consisting 'in the injury offered to reputation, not in any breach of the peace or other consequence that may result from it'. Its 'essence' is the emotional 'pain' it produces. ${ }^{39}$ This relatively narrow definition advances the property-concept over the honour-concept, while also excluding previously common ideas like that of 'libel against religion'. Other reformist proposals are also in evidence: the Code erases the distinction between libel and slander; allows for justification in cases where defamatory claims are both true and their publication in the public good; and offers protection to those expressing 'any opinion whatever' about 'a public servant in the discharge of his public functions' (thus starkly inverting the older concept of 'seditious libel'). ${ }^{40}$

As a civil suit, the Maharaj Libel Case was tried under common law and not the newly enacted Indian Penal Code. Even so, the Code was part of the broader cultural field that shaped the trial. So

37 Rosenberg, Protecting the Best Men, pp. 5-6; Peter Frederick Carter-Ruck, Libel and Slander (Hamden, Conn.: Archon Books, 1973), pp. 37-48.

38 Paul Mitchell, 'The Foundations of Australian Defamation Law', in Sydney Law Review, Vol. 28 (2006), pp. 477-504.

39 W. Morgan and A. J. MacPherson, The Indian Penal Code (Act XLV of 1860), with Notes (Calcutta: G. C. Hay \& Co, 1861), pp. 439-440. Henceforth cited in text as IPC.

40 The section of Macaulay's draft penal code of 1837 that handled sedition was omitted from the 1860 Indian Penal Code, allegedly 'by some unaccountable mistake'. This omission was corrected in 1870 with the addition of section 124-A. See Walter Donagh, The History and Law of Sedition and Cognate Offences (Calcutta: Thacker, Spin, \& Co., 1911), p. 1.; W. R. Hamilton, The Indian Penal Code with Commentary (Calcutta: Thacker, Spink, and Co., 1895), pp. 132-142. For speculation as to the reasons for the omission of the sedition statute, see Aravind Ganachari, Nationalism and Social Reform in Colonial Situation (Delhi: Kalpaz Publications, 2005), pp. 54-57. For a further discussion of the history of British colonial libel law, see Mitra Sharafi, Law and Identity in Colonial South Asia (Cambridge: Cambridge University Press, 2014), pp. 276-285. 
were the many guides to the tort of defamation that had been published in the preceding decades, such as George Cooke's Treatise on the Law of Defamation (1844) and C. G. Addison's Wrongs and their Remedies (1860) (MLC, 76, 60). A full history of libel law in colonial India has, to the best of my knowledge, yet to be written. But given the range of cases during the 1860s alone that were tried or publicized under this rubric (including the Lucknow Libel Case [1860], the Nil Darpan Case [1861], and the Parsi Priest Defamation Case [1870]), as well as the appearance of legal guides (such as Jehangeer Merwanjee's Gujarati manual of Libel and Slander, apparently published on the heels of the Maharaj affair), it would seem that in India, as in Britain, 'libel' remained a relatively mobile concept, the boundaries of which were still in the process of being defined. ${ }^{41}$

For our purposes, we might describe libel as information out of place: it puts into print what should not be there. Libel law, then, tries to make information stay put, ordering it so as to safeguard privacy. But because libel necessarily links the private self to the law and, with it, the public domain, it ensures that the private can never be entirely excluded from public discourse. Rather, the private self is always at risk of being dragged into public to prove itself before the 'tribunal' of juridical and popular opinion $(M L C, 205,209)$. If sexuality is one paradigmatic site whereby the potential for the private to become scandalously public becomes actualized, religion is another. To see how, we return to the Maharaj Libel Case-rejoining the trial in medias res.

\section{Unbecoming Krishna}

'By God, I mean Krishna'. Jumnadas Sevaklal answered tersely, his pinched reply indicating irritation with Thomas Anstey's interrogation of his beliefs. The packed audience looked on as Sevaklal was threatened with a fine of one hundred rupees for evading cross-examination. Under pressure, he had little choice but to elaborate on his previous claim: 'In my opinion, the Maharaj is a representative of Krishna'. Anstey, not content to let the matter rest here, pushed further:

$\begin{array}{ll}\text { Mr. Anstey: } & \text { Do some Banias believe the Maharaj to be a God? } \\ \text { Witness: } & \text { We consider him to be our gooroo. } \\ \text { Sir. M. Sausse: } & \text { Tell witness if he does not answer the question, he will be sent to jail. }\end{array}$

Witness: What is the precise question? (Interpreter explains) Some consider the Maharaj a god in the shape of gooroo.

Mr. Anstey: $\quad$ Is Gooroo a God?

Witness: Gooroo is gooroo.

Sir M. Sausse: $\quad$ Tell him if he does not answer the question, most indubitably he will go to jail.

Sir Joseph Arnould: Tell him he is asked what others believe, not as to his own belief.

Witness: I don't know if others believe him as God; I consider him simply a gooroo. (MLC, 134-36)

Here, the semiotics of devotion strain under the weight of the colonial legal apparatus. Legal institutions were far from neutral or empty sets in which public dramas could unfold. The court was a technology of subjectivation, or rather a set of such technologies-here, the witness stand functions as a sort of confessional booth, which imposes certain unstated rules on the person within it.

41 Action for Libel (Lucknow: Newul Kishore Press, 1860); Parsee Priest Defamation Case (Bombay: Dorabjee Eduljee Tata, 1870); The History of the Nil Darpan, (Calcutta: n.p., 1861); Geoffrey Oddie, Missionaries, Rebellion, and Proto-Nationalism: James Long of Bengal, 1814-87 (New York: Routledge, 2013 [1999]). Merwanjee's Libel and Slander is mentioned in the Bombay Gazette (1 May 1862), p. 412. 
To find voice at court, bhakti (roughly, devotional Hinduism) had to translate itself into the language of propositional belief, reducing the rich relational network of lived religion into dry theological statements like 'Guru is God'. The juridical subject of belief necessarily precedes the proposition that he assents to; otherwise, he would not have the legal standing to grant his assent. Where the Pushtimarg had prized the ideal of 'self-surrender' (atmanivedan), the British court reduces religion to a set of beliefs that a sovereign subject can 'have', thus replacing a faith that unravels the self in the face of the other with a faith that presumes that integrity of the believing subject.

We might say that during the Maharaj Libel Case, the faith binding guru and devotee was rhetorically severed. Half of the relational bond was delivered to the devotees as 'belief'. The other half was given to the guru as his 'reputation'. What had served as a mode of relationship with a potential to erode the boundaries of the self is, in both cases, rendered a form of property that reinforces the sense of discrete personhood. By abstracting the complex web of an individual's social and professional relationships into a discrete object, reputation reifies a community's fluid perceptions as a form of property. In a sense, it inverts the process whereby a subject is hailed by her social order and offered a fixed position within it: one 'has' a reputation, rather than being had by it. In this context, Jumnadas Sevaklal's plaintive refrain ('Gooroo is gooroo') acquires an almost deictic force, pointing toward Jadunathji in his social immediacy as though to underscore the bond between teacher and disciple.

The property concept of reputation was not, of course, alien to India. A version of it had long been central to Gujarati merchant society, where 'the maintenance and improvement of reputation' $(a b r u)$ was a matter with serious financial consequences. ${ }^{42}$ But it was not a merchant's reputation that was on trial during the Maharaj Libel Case. Instead, the court found itself faced with the question of whether a 'spiritual' man like the Maharaj could be defamed in his capacity as a 'private' citizen. Is a priest legally equivalent to members of other, secular professions such as a 'tradesman' $(M L C, 75)$ ? Did the Maharaj even qualify as a 'priest'? What, after all, is the nature of 'spiritual' personhood?

The trial opened with an argument about whether libel law could be applied in this case. Thomas Anstey, the pleader for the defence, pointed out that in Britain a defamed 'ecclesiastic' would file suit in the 'Courts Christian' and not the 'Court of Common Law'. In Bombay Presidency, which had no such courts, there was consequently 'no law of defamation of a spiritual man' ( $M L C$, 8-9). Lyttelton Bayley, arguing for the prosecution, responded that 'this was a libel against the plaintiff not in his spiritual capacity, but in his private character' (ibid., 16). Chief Justice Sausse concurred: it 'was a libel against the plaintiff in his individual capacity, segregated from his character of priest' (19). While the arguments made by both attorneys shifted somewhat during the trial (Bayley later claimed that the plaintiff had been libeled 'in his double capacity as man and as Maharaj' [167]), this basic logic held. There were two persons in court, analytically 'segregated' from one another: the 'spiritual' Maharaj, and the 'private' Jadunath.

The court conceded that Mulji was well within his rights to disparage the first of these persons. Religion, all parties seemed to agree, must remain open to criticism. If calling a religious sect heretical were deemed illegal, argued Anstey, then every Protestant and Catholic journal in England and every philosopher from John Locke forward should be prosecuted, and 'the whole body

42 Douglas Haynes, Rhetoric and Ritual in Colonial India: The Shaping of a Public Culture in Surat City, 1852-1928 (Berkeley: University of California Press, 1991), pp. 38, 56-58. 
of missionaries from the East to the West, who preach against the immorality of heathenism... would be brought up for libel every day!' $(M L C, 19,154-56)$. Judge Arnould added the biblical prophets and church fathers to this list of potential libelers (ibid., 428). In an earlier era of British law, 'libel against religion' was harshly censured. As one early nineteenth-century writer reflected (in discussing a famous early modern case that centered on the claim that 'Christ is a whoremaster, and religion is a cheat'), 'libels against religion... may with equal propriety be said to be libels against the public at large." ${ }^{43}$ They dissolve the moral foundation of society and so endanger the peace to a unique degree.

The cast of characters assembled in the Bombay Supreme Court thought differently. For them, the 'public at large' cohered around a principle other than religion. As has often been observed, the government of British India was generally more secular than its metropolitan counterpart. The law of libel suggests one way in which this was the case. In place of a blasphemy statute (i.e. 'libel against religion'), the Indian Penal Code (Section 298) criminalizes religious offensive publications that wound 'the religious feelings of any person'. Here, protection of religion as a collective cultural form that founds and maintains 'the public at large' is replaced by the protection of the individual 'person', whom the statute presents as preceding her religion. Community, of course, was never far behind. But the wording of the statute does indicate an important shift in how religion was understood under secular law. Criticism of religion per se was now protected, in that it was deemed unthreatening to social order; criticism of the beliefs and feelings of private persons was carefully managed, implying that the social order was now anchored in the sanctity of the liberal individual. ${ }^{44}$

Bayley's response to Anstey's defence of the right to criticize religion is revealing in this regard. If the 'doctrine' implied by denying the Maharaj the right to sue for libel were allowed, he argued, then 'no Brahmin in the land would be safe; he could be slandered and libeled with impunity, and redress denied him because he happened to be a spiritual person' $(M L C, 16)$. Here, 'Brahmin' is effectively redefined as an office distinct from the person who 'happens' to holds it. The check placed upon the criticism of religion derives from the legal distinction between a brahman's 'public' capacity as priest and his 'private' character as an ordinary person: the priest can be criticized with impunity; the private person cannot. This distinction, of course, ignores how the ritual economy of caste Hinduism writes status into the flesh. If a brahman has a private self that is analytically distinct from and more fundamental to him than his spiritual personhood, then we are dealing with something other than the traditional world of caste. 'Spiritual personhood' precedes the self; it does not follow from it.

Something similar holds for the Pushtimargi Maharajas, who were traditionally held to be incarnations of Krishna. A god cannot be libeled (at least in the modern sense of the term) because a god has no private self. To defame a god is to defame all that he represents (e.g. 'the public at large'), but not him personally. By turning 'spiritual personhood' into a mere office, the property-concept of libel prompted an important shift in the legal regulation of religion in that the sanctity of the individual came to replace the sanctity of religion per se as the primary object of legal protection. As long as no 'person' was offended or libeled, one could criticize religion at will.

44 For further consideration of Sections 298 and 295-A, see J. Barton Scott, 'Aryas Unbound: Print Hinduism and the Cultural Regulation of Religious Offence,' Comparative Studies in South Asia, Africa, and the Middle East, Vol. 35, no. 2 (2015): forthcoming. 


\section{Manifestly Divine}

The Pushtimarg, or the 'Way of Grace', had originated with Shri Vallabhacharya (1479-1530), one of the most important early modern exemplars of bhakti. Born to Telugu brahmans, he traveled widely throughout the subcontinent, singing the praises of Krishna and initiating disciples into his sampradaya. In his substantial corpus of written works in Sanskrit and Braj Bhasha, he developed the philosophical system of shuddhadvaita (pure non-dualism), which modified the earlier monism of Shankaracharya by eliminating the notion of maya. Additionally, Vallabhacharya married and had two sons, Gopinath (1512-1542) and Vitthalnath (1515-1585) — a fact of decisive importance for his sampradaya, which does not prize celibacy like many other Hindu lineages. When Vallabha died, his spiritual authority passed to these two heirs. Vitthalnath assumed greater authority, and his seven sons (Vallabha's grandsons) established the 'Seven Houses' that remain the sect's major structuring institution. Control of the houses is inherited via primogeniture, although all of Vallabha's descendants through the male line are typically termed 'Maharajas'. From the sixteenth through the eighteenth century, these religious leaders pursued the patronage of commercial and political elites in Rajasthan, Gujarat, and elsewhere in northern and western India- growing wealthy in the process. ${ }^{45}$

Pushtimargis consider both Vallabha and his son Vitthalnath to have been incarnations of Krishna. Their immediate followers, meanwhile, are considered incarnations of the gopis (the cowherding girls who were Krishna's consorts). When these first two generations of Pushtimargi devotees died, they resumed their divine play in heaven. ${ }^{46}$ What happened next is controversial. As Jadunathji Brizratanji insisted during the Maharaj Libel Case, 'Vallabhacharya and his son Gosaijee [Vitthalnath] are regarded as incarnations of God but not so the sons of Gosaijee' ( $M L C$, 170). Given the quantity of contradictory testimony, however, it seems likely that Jadunathji was misrepresenting popular belief in his community; many Banias and Bhattias in the 1850s and 60s do seem to have considered these later Maharajas to be divine. Gopalldas Mahadevdass, the head of the Bania Mahajun, probably summarized the situation fairly accurately when he explained to the court that '[s]ome people do say that they are gods, while some deny that they are' (ibid., 62).

The simple equation 'Guru is God', however, is too reductive a summary of what is going on here. The Maharaj was not divine in and of himself; he was divine insofar as he represented Krishna. To develop a more nuanced picture of the Pushtimarg's semiotics of devotion, we can turn to the religious practices described during the trial. By Mahadevdass's account, the Maharajas worship the 'idols', while ordinary men and women worship the Maharajas:

They prostrate themselves at the Maharaj's feet. By worshipping the Maharaj, I understand applying to him scent and stuff, and offering him fruits and flowers, in the same way as the idols are worshipped. When we fall down before the Maharaj, he blesses us. One mode of worshipping the idol is by swinging it, and our women worship the Maharaj by swinging him. (MLC, 63)

45 Thoothi, Vaishnavas of Gujarat, pp. 92-98; Richard Barz, The Bhakti Sect of Vallabhacarya (Faridabad: Thomson Press, 1976); Shandip Saha, 'Creating a Community of Grace: A History of the Pushti Marga in Northern and Western India, 1479-1905' (Ph.D. thesis, University of Ottawa, 2004), pp. 107-127. A series of recent legal disputes in Rajasthan over whether Pushtimargi temples are 'public' or 'private' (nij) entities would provide an interesting topic for further research. See Peter Bennett, The Path of Grace: Social Organization and Temple Worship in a Vaishnava Sect (Delhi: Hindustan Publishing Corporation, 1993), pp. 83, 172-75. 
Additionally, devotees eat the 'remnants' of the Maharaj's food and paan, as well as drinking 'the water rinsed and rung' from his dhoti (termed charanamrit, or 'nectar of the feet'). Other witnesses gave similar testimony.

The question remains as to how one should read such practices. Was the Maharaj an index, an icon, or a symbol of the divine? One view would opt for the index: as an incarnation, the Maharaj has a direct physical relationship to Krishna. This indexical logic, moreover, permeates many of the religious practices discussed during the Maharaj Libel scandal, as Christopher Pinney has suggested: one eats the dust from the guru's feet because that dust is a physical trace of him; ingestion of it incorporates the guru into the self. ${ }^{47}$ Here, the guru is semiotically porous, bleeding out into his followers via the same kind of indexical connection that links him to Krishna.

Another view would align the guru with the icon (i.e. the image that provides a likeness of Krishna). As the Rast Goftar and Satya Prakash explained: 'The Maharajas serve the image [murti], and devotees cannot serve the image, and so instead [tene badale] they serve the Maharaj', as by rocking him in a swing or offering him flowers and fruit just he does to the murti. ${ }^{48}$ The use of the word murti here is tendentious. Within the Pushtimarg, as Richard Barz explains, the divine image is never referred to as a murti (representation) but rather as a svarup (the 'entity itself, not a likeness'). ${ }^{49}$ Devotional images are the self-manifestations of Krishna; like avatars, they participate indexically in the divine. Thus, while it might seem that there is an arbitrary exchange (badal) or substitution between two independent entities, in the mode of the symbol, what we actually see here are two entities that index a common referent; murti and avatar are two types of spark issuing from a single fire.

There are good metaphysical reasons for this. The phenomenal world, according to Vallabhacharya, comes to exist when Brahman (or the Ultimate) 'conceals part of himself'. This is the process that Vallabha calls tirobhava ('concealment, act of hiding, becoming invisible'; 'capability of not becoming an object of experience'). Brahman consists of three parts: being, consciousness, and bliss (sat, cit, and ananda). In the physical world, only being is in its 'manifest' or 'apparent' (avirbhuta) condition; in the soul (jiva), both being and consciousness are manifest. The problem of samsara, then, is a problem of wrong understanding: the soul understands that it exists, but not that it is part of Brahman-Krishna. Once it attains this understanding, it achieves bliss (or, rather, its innate bliss becomes manifest). ${ }^{50}$ Shuddhadvaitic metaphysics, it would seem, precludes a strict ontological distinction between sign and referent: insofar as all beings participate in BrahmanKrishna, all beings bear an indexical relationship to one another. As a 1910 primer on Pushtimargi principles succinctly puts it, 'Nothing is distinct from the Ultimate Being [parabrahm]'.51

To say that the Maharaj is God, then, is simply to state the obvious: all entities are God,

47 Christopher Pinney, The Coming of Photography in India (London: British Library, 2008), pp. 114-117.

48 Rast Goftar and Satya Prakash (23 Feb 1862), p. 91.

49 Barz, Bhakti Sect, p. 9

50 Barz, Bhakti Sect, pp. 63-71; Mrudula Marfatia, The Philosophy of Vallabhacharya (Delhi: Munshiram Manoharlal, 1967), pp. 48-54.

51 Patvari Raṇchoddas Vandravandas, Pushțimargiya Siddhant athava Shuddhadvaitna Multattva, vol. 1 (Ahmedabad: Gujarat Printing Press, 1910), p. 101. 
whether they realize it or not. ${ }^{52}$ Such subtleties were, of course, lost on the Bombay Supreme Court. Even so, by reading the Pushtimarg to highlight the doctrine of 'concealment' (tirobhava), we discover a surprising resonance between its theology and colonial law: both were preoccupied with what we might, by creatively stretching our translations, term publicity. If the public (jaher) is that which is 'outward' or 'apparent', then the public is very much analogous to the 'manifest' (avirbhuta) aspects of the Pushtimargi divine. Both, in fact, take the 'secret' ( $g u p t$ ) as their primary antonym. ${ }^{53}$ If the Maharaj is a manifestation of Krishna, a making visible of the divine in the world, then he is, by definition, always already jaher.

I do not, of course, mean to suggest that Advaitic metaphysics and the colonial public's epistemology of exposure are somehow the same. They aren't. But by aligning them in this way we can begin to develop an alternative narrative that presents religion as plying something other than (in the words of the Bombay Gazette and Times of India) 'darkness'. Like colonial print culture, the Pushtimarg organizes a particular distribution of the visible that likewise implies particular notions about the nature of human personhood. As Sandria Freitag has counseled, in constructing a genealogy of the public in colonial South Asia, we need to look for the "indigenous bases onto which western European notions of "the public" could have been grafted'. ${ }^{54}$ Pushtimargi metaphysics appears as one such base, especially when juxtaposed to Karsandas Mulji's translation of public as jaher.

\section{Conclusion}

After the trial, Jadunathji Brizratanji and several other Maharajas quickly left Bombay, lest they be indicted for perjury. ${ }^{55} \mathrm{Mulji}$, meanwhile was feted for several months by his fellow reformists. ${ }^{56}$ Eventually, however, he too moved on to new challenges - most notably, a voyage to England that furthered antagonized caste authorities. Some commentators predicted that the libel case would extinguish belief in the Maharaj, but its actual outcomes proved considerably more ambivalent. One newspaper noted that the scandal had 'only increased the ardour' of the Pushtimargis' devotion. ${ }^{57}$ Years later, another critic complained that the 'incomprehensible psychological phenomenon' of 'Maharajism' had persisted unscathed. ${ }^{58}$ In reality, this was not entirely true. The trial, as Jürgen Lütt has argued, presaged a widespread retreat from the erotics of Krishna devotion that became

52 Bennett, The Path of Grace, pp. 39-40, 59-60.

53 Vandravandas's Pushtimargiya Siddhant seems to use gupt and tirobhav more or less interchangeably. Āvirbhāv, meanwhile, becomes prakat, when shifted from technical to more ordinary Gujarati. It is possible that author thought the Arabic-root jaher as too 'Islamic' to be used in a Hindu devotional context.

54 Sandria Freitag, "Introduction: Aspects of the Public in Colonial South Asia," in South Asia: Journal of South Asian Studies, Vol. 14, no. 1 (1991), p. 7.

55 Bombay Gazette (3 May 1862), p. 420.

56 Bombay Gazette (16 July1862), p. 672.

57 Poona Observer (11 March1862), supplement, pp. 1-2

58 Behramji M. Malabari, Gujarat and the Gujaratis (Delhi: Mittal Publications, 1983 [1889]), pp. 226-227. 
more pronounced by the early twentieth century. ${ }^{59}$ The Pushtimarg seems to have participated in this general trend-at least in its self-presentation to the Gujarati print public. For instance, as its title suggests, the book Pushtimargi Principles, or the Original Form of Pure Non-Dualism (1910) emphasizes Vallabhacharya's monistic philosophy over the affective practices of Krishna worship. Strenuously denying the by-then common claim that pushti means 'to eat, to drink, and to become contented', its author sets out to prove by copious textual example that Pushtimargi teachings are fully concordant with those of the Vedas, the Gita, and other canonical scriptures. ${ }^{60}$ One can see here how the trial shaped and constrained the Pushtimarg for years to come.

One might ask whether this story could have ended differently. For example, what would have happened if Mulji had reframed the anglophone rhetoric of public 'exposure' in terms of the Pushtimargi notion of divine 'manifestation'? Could he, by more carefully managing not only his medium but also the cultural idioms that accompanied it, have articulated a more effective critique of the Maharajas? Perhaps.

Regardless, it might seem safest to accept a piece of old advice that was revived during the trial: 'Better have no opinion of God at all than an injurious one. ${ }^{61}$ But upon closer inspection, one finds that this early modern maxim is not so easily transposed to the nineteenth century. Journalists in Victorian India frequently quoted English Enlightenment classics; but in doing, they tended to neglect how the world had changed since the days of Francis Bacon. This was certainly case with respect to the state's management of religion. In 1862, it seems, 'injurious' opinions about God were, in themselves, legally permissible; injury to the reputation or feelings of the individual person, on the other hand, was the object of careful regulation.

60 Vandravandas, Pushtimargiya Siddhant, pp. vi-vii, 2-5.

61 Francis Bacon, as quoted in the Bombay Gazette (4 Dec. 1861), p. 1158. 